\title{
Insulin and insulin-like growth factor-1 modulate the lipolytic action of growth hormone by altering signal pathway linkages
}

\author{
Heather E. Bergan-Roller ${ }^{\mathrm{a}}$, Alicia T. Ickstadt, Jeffrey D. Kittilson, and Mark A. Sheridan ${ }^{\mathrm{b}^{*}}$ \\ Department of Biological Sciences, North Dakota State University, Fargo, ND 58105, USA
}

Running head: modulation of growth hormone actions

Address correspondence and send proofs to:

Dr. Mark A. Sheridan

Department of Biological Sciences

Texas Tech University

Lubbock, TX 79409, USA

Tel: 806-742-2781

FAX: 806-742-4038

E-mail: mark.sheridan@ttu.edu

* Corresponding author. Tel.:+1 806 742-2781; fax +1 8067424038.

E-mail address: mark.sheridan@ttu.edu (M.A. Sheridan)

${ }^{a}$ Present address: School of Natural Resources, University of Nebraska, Lincoln, Nebraska 68583 USA

${ }^{\mathrm{b}}$ Present address: Department of Biological Sciences, Texas Tech University, Lubbock TX 32 79409 USA 


\section{ABSTRACT}

45 Growth hormone $(\mathrm{GH})$ has many actions in vertebrates, including the regulation of two

46 disparate metabolic processes: growth promotion (anabolic) and the mobilization of stored lipids

47 (catabolic). Our previous studies showed that GH stimulated IGF-1 production in hepatocytes

48 from fed rainbow trout, but in cells from fasted fish GH stimulated lipolysis. In this study, we

49 used rainbow trout (Oncorhynchus mykiss) to elucidate regulation of the mechanisms that enable

50 cells to alter their lipolytic responsiveness to GH. In the first experiment, cells were removed

51 from either fed or fasted fish, conditioned in medium containing serum (10\%) from either fed or

52 fasted fish, then challenged with GH. GH stimulated the expression of hormone sensitive lipase

53 (HSL), the primary lipolytic enzyme, in cells from fasted fish conditioned with "fasted serum"

54 but not in cells from fasted fish conditioned in "fed serum." Pretreatment of cells from fed fish

55 with "fasted serum" resulted in GH-stimulated HSL expression, whereas GH-stimulated HSL

56 expression in cells from fasted fish was blocked by conditioning in "fed serum." The nature of

57 the conditioning serum governed the signaling pathways activated by GH irrespective of the

58 nutritional state of the animals from which the cells were removed. When hepatocytes were

59 pretreated with "fed serum," GH activated JAK2, STAT5, Akt, and ERK pathways; when cells

60 were pretreated with "fasted serum," GH activated PKC and ERK. In the second study, we

61 examined the direct effects of insulin (INS) and insulin-like growth factor (IGF-1), two

62 nutritionally-regulated hormones, on GH-stimulated lipolysis and signal transduction in isolated

63 hepatocytes. GH only stimulated HSL mRNA expression in cells from fasted fish. Pretreatment

64 with INS and/or IGF-1 abolished this lipolytic response to GH. INS and/or IGF-1 augmented GH

65 activation of JAK2 and STAT5 in cells from fed and fasted fish. However, INS and/or IGF-

66 1eliminated the ability of GH to activate PKC and ERK from fasted cells. These results indicate 
67 that INS and IGF-1 determine the signaling pathways activated by GH and whether or not a

68 lipolytic response ensues. Such hormone-receptor-signal pathway linkages provide insight into

69 the molecular basis of GH multifunctionality and into how cellular responses to GH can be

70 adjusted to meet physiological (e.g., nutritional), developmental, or other conditions.

71

72 Keywords: Signal transduction, rainbow trout (Oncorhynchus mykiss), hepatocytes, hormone

73 sensitive lipase, insulin, insulin-like growth factor 


\section{Introduction}

The brain-pituitary-liver axis and endocrine pancreas play major roles in coordinating

76 growth and metabolism. When food is available, anabolic conditions prevail and growth ensues.

77 Plasma insulin (INS) peaks in the circulation after a meal to facilitate the uptake of glucose and

78 amino acids into cells through a receptor tyrosine kinase and downstream activation of PI3K,

79 SHP2, fyn, and several adaptors (SOCS1 and 3) (Mommsen and Plisetsakya, 1991; White,

80 2003). Secretion of growth hormone (GH) also increases following feeding and results in

81 growth-related responses in target cells (e.g. increased amino acid uptake, increased RNA

82 synthesis, increased protein synthesis, increased cartilage synthesis, and increased muscle

83 growth); some of these resulting from direct actions of GH and others mediated by insulin-like

84 growth factor-1 (IGF-1), which is produced by the liver and other cells (Butler and LeRoith,

85 2001; Reinecke et al., 2005). GH stimulates hepatic production and release of IGF-1 in fish

86 through activation of the JAK-STAT, PI3K/Akt, and ERK signaling pathways (Reindl et al.,

87 2011).

By contrast, during periods of fasting, catabolic conditions prevail and growth is

89 suspended and energy stores are mobilized to fuel metabolic functions. In all groups of

90 vertebrates studied, from fish to humans, plasma levels of INS and IGF-1 decline whereas

91 glucagon levels increase (Norbeck et al., 2007; Pierce et al., 2005; Salgin et al., 2012). The

92 cessation of growth appears to result from the reduced signaling pathways associated with INS

93 and IGF-1 (Duan and Xu, 2005; Taniguchi et al., 2006). The decrease in IGF-1 occurs despite

94 the enigmatic observation that plasma GH is elevated during fasting (Norbeck et al., 2007; Pierce

95 et al., 2005; Salgin et al., 2012). The mobilization of energy reserves (glycogen, lipid) results

96 from the actions of glucagon and GH (Albalat et al., 2005; Harmon and Sheridan, 1992; 
97 O’Connor et al., 1993; Sheridan and Mommsen, 1991; Sheridan, 1994; Sos et al., 2011).

98 Hormone sensitive lipase (HSL) is a major lipolytic enzyme that breaks down stored lipids (Watt 99 and Spriet, 2010). It has been well characterized in adipose tissue of mammals (Lafontan and 100 Langin, 2009) and in adipose tissue and liver of fish (Sheridan, 1994). Uniquely, fish possess 101 two HSL-encoding mRNAs that are differentially expressed among tissues (Kittilson et al., 102 2011). Enhanced lipolysis results from increased HSL expression along with post-translational 103 phosphorylation of HSL (Bergan et al., 2013; Watt and Spriet, 2010). We recently demonstrated

104 that the lipolytic actions of GH on HSL are mediated through activation of the ERK and 105 PKC/PLC pathways (Bergan et al., 2013).

106 The major question arising from these foregoing observations is how does GH have 107 growth-promoting actions during periods of feeding and lipolytic actions during periods of 108 fasting. In recent experiments we found that JAK-STAT and Akt pathways are activated 109 concomitantly with deactivation of the PKC and ERK pathways during periods of feeding (and 110 growth) whereas the PKC and ERK pathways were activated concomitant with deactivation of the 111 JAK-STAT and Akt pathways during periods of fasting (and growth cessation) (Bergan et al., 112 2012). We also found that GH activated the JAK-STAT and Akt pathways in hepatocytes from 113 fed trout resulting in enhanced IGF-1 expression but no effect on HSL expression (Bergan et al., 114 2015; Walock et al., 2011). By contrast, GH activated the PKC/PLC and ERK pathways in 115 hepatocytes from fasted fish resulting in enhanced HSL expression but no effect on IGF-1 116 expression (Bergan et al., 2015; Walock et al., 2011). Moreover, blockade of the PKC/PLC and

117 ERK pathways abolished GH-stimulated HSL expression (Bergan et al., 2015). From these 118 findings, we conclude that nutritional state acts to "reprogram" the responsiveness of hepatocytes 119 to GH. 
121 responsiveness to GH. Given previous observations that plasma levels of INS and IGF-1 differ

122 with nutritional status (cf. Norbeck et al., 2007), we developed the working model that INS and

123 IGF-1 alter the signal pathways to which growth hormone receptors (GHR) link to influence the

124 specific cellular response. The hypothesis of this study was that INS and IGF-1 redirects GHR

125 linkage away from the PKC/PLC and ERK pathways to the JAK/STAT and PI3K/Akt pathways

126 and results in the inactivation of lipolysis.

\section{2. Materials and Methods}

\section{2.1. Materials}

130 All chemicals and reagents used were purchased from Sigma (St. Louis, MO, USA)

131 unless stated otherwise. Antibodies for the phospho-specific and total (recognizing both

132 phosphorylated and nonphosphorylated protein) forms of Akt, ERK1/2, JAK2, PKC $\alpha / \beta$ II, and

133 STAT5, horseradish peroxidase (HRP)-linked anti-rabbit IgG antibody, biotinylated molecular

134 weight marker, anti-biotin-HRP antibody, and cell lysis buffer were all obtained from Cell

135 Signaling Technology (Beverly, MA, USA). Bovine INS was obtained from Sigma, ovine IGF-1

136 was obtain from the NIH National Hormone and Pituitary Program, and salmonid GH was

137 generously provided by Prof. Akiyoshi Takahashi and Dr. Shinsuke Moriyama (Kitasato

138 University, Japan).

\section{2.2. Experimental animals and conditions}

140 Juvenile rainbow trout of both sexes ( $c a .1$ year of age; 88.1 $55.3 \mathrm{~g}$ ) were obtained from

141 Dakota Trout Ranch (Carrington, ND). The animals were transported to North Dakota State

142 University where they were maintained in well-aerated, 800-L circular tanks supplied with 
143 recirculated (10\% make-up volume per day) dechlorinated municipal water at $14^{\circ} \mathrm{C}$ under a

144 12:12 hour light:dark photoperiod. Fish were fed twice daily to satiety with AquaMax Grower

145 (PMI Nutrition International, Brentwood, MO, USA; 45\% crude protein, $16 \%$ crude fat, $3 \%$ crude

146 fiber) semi-floating trout grower until commencing experiments where fish were fasted

147 continuously for 4 weeks or fed continuously for 4 weeks. Fed fish were fasted 2 hours before

148 experimental manipulations. Animals were acclimated to laboratory conditions for at least 4

149 weeks prior to experimentation and sampling occurs at the same time of day. All procedures

150 were performed in accordance with the Guide for the Care and Use of Laboratory Animals, 8th

151 edition (National Research Council, Washington, DC) and were approved by the North Dakota

152 State University Institutional Animal Care and Use Committee.

153 At the time of sampling, fish were anaesthetized in $0.05 \%(\mathrm{v} / \mathrm{v}) 2$-phenoxyethanol,

154 measured (body weight and fork length) and euthanized by transection of the spinal cord.

155 Withsome fish, whole blood was collected by caudal venipuncture (Galt et al., 2014), incubated 156 at $4{ }^{\circ} \mathrm{C}$ for 1 hour to allow clotting, then centrifuged $(11,000 \mathrm{~g}, 3 \mathrm{~min})$ to secure only the serum.

157 Serum was either used that day to treat cells or stored at $-80^{\circ} \mathrm{C}$ for later analysis. With other fish,

158 hepatocytes were isolated by in situ perfusion (Mommsen et al., 1994). The isolated cells were

159 incubated in recovery medium [in mM: $137.8 \mathrm{NaCl}, 5.4 \mathrm{KCl}, 0.80 \mathrm{MgSO}_{4}, 0.4 \mathrm{KH}_{2} \mathrm{PO}_{4}, 0.34$

$160 \mathrm{Na}_{2} \mathrm{HPO}_{4}, 4.2 \mathrm{NaHCO}_{3}$, and 10 HEPES, 0.65 glucose, pH 7.6, with 2\% defatted BSA, 2 ml MEM

161 amino acid $\operatorname{mix}(50 \mathrm{X}) / 100 \mathrm{ml}$, and $1 \mathrm{ml}$ nonessential amino acid mix $(100 \mathrm{X}) / 100 \mathrm{ml}]$ for $2 \mathrm{~h}$ at

$16214^{\circ} \mathrm{C}$ with gyratory shaking $(100 \mathrm{rpm})$ under $100 \% \mathrm{O}_{2}$. The viability of the cells was assessed by

163 trypan blue dye exclusion and ranged between 93-97\% for all experiments. After the recovery

164 period, hepatocytes were collected by centrifugation (550 $\mathrm{g}$ for 8-10 min) and resuspended in 
165 incubation media (recovery media with $1.5 \mathrm{mM} \mathrm{CaCl}_{2}$ ) to a final concentration of $2.3 \times 106$

166 cells $/ \mathrm{ml}$ and aliquoted into $24-w e l l$ plates $(2.3 \times 106$ cells/well).

167 For the first experiment, cells were incubated in medium containing serum $(10 \% \mathrm{v} / \mathrm{v})$ from

168 fed ([INS] $12 \mathrm{ng} / \mathrm{ml}$; [IGF-1] $212 \mathrm{ng} / \mathrm{ml}$ ) or fasted fish ([INS] $\sim 1.4 \mathrm{ng} / \mathrm{ml}$; [IGF-1] 107

$169 \mathrm{ng} / \mathrm{ml}$ ) and without (control) or with exogenous $\mathrm{GH}(100 \mathrm{ng} / \mathrm{ml})$ under the same conditions as

170 those used for recovery $\left(14^{\circ} \mathrm{C}\right.$ with gyratory shaking at $100 \mathrm{rpm}$ under $\left.100 \% \mathrm{O}_{2}\right)$. The eight

171 resulting experimental groups were as follows: fed cells fed serum without GH (fed-fed control),

172 fed-fed with GH, fed cells fasted serum control, fed-fasted with GH, fasted cells fed serum

173 control, fasted-fed with GH, fasted cells fasted serum control, and fasted-fasted with GH.

174 For the second experiment, fed or fasted cells were incubated in GH, INS and GH, IGF-1

175 and GH, or INS, IGF-1 and GH. The ten resulting experimental groups were as follows: fed cells

176 alone, fed cells with GH, fed cells with INS and GH, fed cells with IGF-1 and GH, fed cells with

177 INS, IGF-1, and GH, fasted cells alone, fasted cells with GH, fasted cells with INS and GH,

178 fasted cells with IGF-1 and GH, fasted cells with INS, IGF-1, and GH. Concentrations of 100

$179 \mathrm{ng} / \mathrm{ml}$ for INS, $200 \mathrm{ng} / \mathrm{ml}$ for IGF-1, and $100 \mathrm{ng} / \mathrm{ml}$ of GH were used; concentrations were

180 selected to mimic "fed" conditions based on previous data (Mommsen and Plisetskaya, 1991;

181 Pierce et al., 2005; Norbeck et al., 2007). For all experiments, serum, INS, or IGF treatments

182 lasted for $24 \mathrm{~h}$ then another $30 \mathrm{~min}$ (for Western blot analysis) or $6 \mathrm{~h}$ (for mRNA expression)

183 with or without GH. After incubation, cells were pelleted (1,000 $\mathrm{xg}$ for $4 \mathrm{~min})$ and the

184 supernatant medium was removed. Cells were washed with $0.5 \mathrm{ml}$ phosphate- buffered saline.

185 Cell pellets were immediately frozen on dry ice then stored at $-80^{\circ} \mathrm{C}$ until further analysis. 
Total RNA was extracted using RNAzol-Reagent® (Molecular Research Center, Inc.,

190 Cincinnati, OH, USA) as specified by the manufacturer's protocol. Each RNA pellet was

191 redissolved in 35-100 $\mu$ l RNase-free deionized water and quantified by NanoDrop1000

192 spectrophotometry (A260) (Thermo Scientific, West Palm Beach, FL, USA). RNA samples were

193 then stored at $-80^{\circ} \mathrm{C}$ until further analysis. mRNA was reverse transcribed in $5 \mu$ reactions using

194200 ng total RNA and AffinityScript QPCR cDNA Synthesis kit reagents (Master Mix, random

195 primers, oligo-dT primers, and reverse transcriptase with block) according to the manufacturer's

196 protocol (Stratagene, La Jolla, CA, USA). Reactions without reverse transcriptase were included

197 as negative controls to exclude the possibility of contamination from genomic DNA; no

198 amplification was detected in negative controls.

Steady-state levels of HSL1 (HQ225622) and HSL2 (HQ225623) mRNAs were

200 determined by quantitative real-time PCR as described previously (Kittilson et al., 2011).

201 Briefly, real-time reactions were carried out for samples, standards, and no-template controls in

202 multiplex reactions with $\beta$-actin and either HSL1 or HSL2. Reactions contained $2 \mu 1 \mathrm{cDNA}$ from

203 the reverse transcription reactions, $5 \mu$ Brilliant® II QPCR Master Mix (Stratagene), $1 \mu 1$ of

204 each $150 \mathrm{nM}$ gene-specific probes, $0.5 \mu 1$ of $600 \mathrm{nM}$ gene-specific forward and reverse primers, 205 and $0.15 \mu \mathrm{l}$ reference dye (Stratagene, Agilent Technologies). Cycling parameters were set as 206 follows: $95^{\circ} \mathrm{C}$ for $10 \mathrm{~min}$ and 45 cycles of $95^{\circ} \mathrm{C}$ for $30 \mathrm{~s}$ and $58^{\circ} \mathrm{C}$ for $1 \mathrm{~min}$. Cross reaction was 207 assessed by substituting alternate primer/probe sets in assays for each standard; no amplification 208 was observed under these conditions. Sample copy number was calculated from the threshold 209 cycle number $\left(\mathrm{CT}_{\mathrm{T}}\right)$ and relating $\mathrm{C}_{\mathrm{T}}$ to a gene-specific standard curve, followed by normalization 210 to $\beta$-actin (the expression of which was not affected by experimental treatments). 
213 Beverly, MA) with 1mM PMSF, 1x protease inhibitor (Calbiochem, San Diego, CA, USA), and 1x

214 phosphotase inhibitor (G-Biosciences, St. Louis, MO, USA). The homogenate was incubated on

215 ice for 5 minutes then centrifuged at $16,000 \mathrm{x}$ g for $10 \mathrm{~min}$ at $4^{\circ} \mathrm{C}$. The protein concentration of

216 the supernatant was determined by the Bio-Rad (Hercules, CA, USA) dye-binding method for

217 microplates. Protein $(50 \mu \mathrm{g})$ was separated by SDS-PAGE (7.5\% running gel) and transferred to

$218 \quad 0.45 \mu \mathrm{m}$ nitrocellulose (Bio-Rad Laboratories) for western analysis as previously described

219 (Bergan et al., 2012; Reindl et al., 2011). Membranes were washed and visualized with

220 chemiluminescence according to the manufacturer's instructions (GE Healthcare,

221 Buckinghamshire, UK); chemiluminescence was detected directly and the bands quantified with a 222 FluorChem FC2 imager (Alpha Innotech Corp, San Leandro, CA, USA). The abundance of 223 phosphorylated ERK 1/2, Akt, JAK2, STAT5, and PKC $\alpha / \beta$ II was normalized to total ERK 1/2,

224 Akt, JAK2, STAT5, and $\beta$-actin, respectively. The use of these commercial antisera to detect 225 signal elements in rainbow trout was previously validated (Bergan et al., 2012; Reindl et al., 226 2011).

227 2.5. Data analysis.

228 Statistical differences were estimated by one-way ANOVA. Pairwise comparison of 229 simple effects was assessed by Duncan's multiple range test; statistical notations on the faces of 230 the figures reflect such comparisons. A probability level of 0.05 was used to indicate

231 significance. All statistics were performed using SigmaStat v. 1.0 (SPSS, Chicago, IL, USA), 232 and graphs and curve fitting models were constructed with SigmaPlot v8.0 (SPSS). Quantitative 233 data are shown relative to control ease of comparison and are expressed as means \pm S.E.M. For 
234 experiment one, the fed cells fed serum control group was designated as the control for both fed 235 and fasted cells.

\section{3. Results}

238 3.1. Serum alters HSL mRNA expression and GH pathway activation

239 Serum affected the expression of HSL mRNA. In fed-fed samples, GH failed to stimulate 240 expression of HSL mRNA (Fig 1A). When pretreated with fasted serum, in the fed-fasted control 241 group, HSL2 mRNA was significantly expressed over the fed-fed control. When the fed-fasted 242 group was treated with GH, expression of both HSL1 and HSL2 mRNAs was greater than the fed-

243 fed control, with HSL2 mRNA being expressed to a greater extent than HSL1 mRNA. Levels of 244 HSL mRNAs from the fasted-fasted control group did not differ from the fed-fed control (Fig. 1B). 245 However, when the fasted-fasted group was treated with GH, expression of HSL mRNAs were 246 greater than the fed-fed controls but not the fasted-fasted controls. Interestingly, when fasted cells

247 were pretreated with fed serum, in the fasted-fed group, the response to GH was abolished such that 248 expression of HSL mRNAs in the fasted-fed control and fasted-fed GH groups were similar to 249 the fed-fed control.

250 Serum influenced signaling pathways activated by GH. Activation of cell signaling 251 pathways by GH was studied in lysates of hepatocytes isolated from 4-week fasted fish and from 252 fish fed continuously and treated with serum. Activated (i.e., phosphorylated) forms of JAK2, 253 STAT5, Akt, ERK, and PKC were detected in lysates of hepatocytes from all treatment groups. 254 In the fed-fed group, GH significantly increased phosphorylation of JAK2 (Fig. 2A), STAT5 (Fig. 255 2C), Akt (Fig. 2E), and ERK (Fig. 2G) but not PKC (Fig. 2I). However, when either cell type 256 (fed and fasted) was pretreated with fasted serum, GH-stimulated phosphorylation of JAK2, 
STAT5, and Akt was abolished. Additionally the fed-fasted control and the fasted-fasted control

258 groups had significantly less phosphorylation of JAK2, STAT5, and Akt than fed-fed control (Figs.

259 2A-2F). GH augmented phosphorylation of ERK and PKC in both fed and fasted cell types when

260 pretreated with fasted serum above that of the fed-fed control, fed-fasted control, and fasted-

261 fasted control (Figs 2G-2J). In this study, serum treatments modified the expression of HSL

262 mRNAs and activated signaling pathways to reflect the serum type (fed or fasted) and not the

263 cell type (fed or fasted).

264 3.2. INS and IGF-lalter HSL mRNA expression and GH pathway activation

265 INS and IGF-1 are tightly regulated by nutritionals state; both hormones peak postprandially

266 and are diminished in fasting vertebrates (Mommsen and Plisetskaya, 1991; Pierce et al., 2005;

267 Norbeck et al., 2007; Shimizu et al., 2009 ). We investigated INS and IGF-1 as possible factors

268 mediating the altered expression of HSL mRNAs and activation of signaling pathways caused by

269 serum described in the previous section. Like serum, INS and IGF-1 altered expression of HSL

270 mRNAs. In experimental groups with fed cells, GH, INS, and IGF-1 pretreatments did not affect

271 expression of HSL mRNAs (Fig. 3A). Basal expression of HSL mRNAs was slightly greater in

272 fasted cells compared to fed cells. In fasted cells, GH stimulated expression of HSL mRNAs

273 above fasted control (Fig. 3B). However, pretreatment of fasted cells with INS and/or IGF-1

274 abolished GH-stimulated expression of HSL mRNAs.

275 INS and IGF-1 influenced signaling pathways activated by GH. In fed cells, GH

276 significantly increased phosphorylation of JAK2 (Fig 4A), STAT5 (Fig. 4C), and ERK (Fig. 4E)

277 but not PKC (Fig. 4G). Similarly in fasted cells, pretreatment with INS and/or IGF-1 augmented

278 GH-stimulated phosphorylation of JAK2 (Fig 4A) and STAT5 (Fig 4C). Additionally in fasted

279 cell, GH alone stimulated phosphorylation of ERK (Fig. 4F) and PKC (Fig. 4H). However, GH- 
280 stimulated phosphorylation of ERK and PKC was abolished when cells were pretreated with INS

281 and/or IGF-1. Taken together, these results suggest that INS and IGF-1 are key factors in serum

282 that regulate the metabolic mechanisms of action of GH including expression of HSL mRNAs

283 and activation of signaling pathways.

284

285 4. Discussion

Previous work from our laboratory demonstrated that nutritional state acts as a switch to

287 "reprogram" the responsiveness of hepatocytes to GH (Bergan et al., 2015). The results of the

288 current study elucidates the mechanisms through which nutritional state alters the responsiveness

289 of hepatocytes to GH and confirms our starting hypothesis that INS and IGF-1 redirects GHR

290 linkage away from the PKC/PLC and ERK pathways to the JAK/STAT and PI3K/Akt pathways

291 and results in the inactivation of lipolysis. The findings provide demonstrate that GHR

292 differentially link to signal pathways that provides new insight into the mechanistic basis of the

293 pleiotropic actions of GH and that helps resolve the disparate growth-promoting (anabolic) and

294 lipolytic (catabolic) actions of GH.

295 Nutritional state modulates the lipolytic responsiveness of hepatocytes to GH. This

296 conclusion is based on several observations. First, hepatocytes isolated from either fed fish or

297 from fasted fish displayed higher basal rates of lipolysis (as measured by HSL expression) than

298 hepatocytes incubated in plasma from fed fish — an observation consistent with our previous

299 findings that basal lipolysis is higher in hepatocytes from fasting fish than in cells from fed fish

300 (Bergan et al., 2015). Second, pretreatment of hepatocytes with serum from fasting fish

301 augmented HSL mRNA expression regardless of the nutritional state from which the cells came.

302 Moreover, only when cells were treated with fasting serum was GH able to stimulate HSL 
mRNA expression over levels observed in fed controls. GH-stimulated lipolysis has been

304 reported previously in fish and mammals (Albalat et al., 2005; Bergan et al., 2013, 2015; Chavez

305 et al., 2006; Gorin et al., 1990; O'Connor et al., 1993); however, GH also has been reported to

306 have anti-lipolytic effects in mammals (Richelsen, 1997). The antilipolytic, insulin-like effects in

307 mammals are short-term and are observed in adipose tissue not previously exposed to GH (i.e.,

308 from hypophysectomized animals or from cells of normal individuals preincubated in the absence

309 of GH for 2-4h). Given the conditions under which it is brought, the biological significance of

310 the antiploytic, insulin- like effects of GH has been questioned (Carrel and Allen, 2000). Our

311 current and previous findings (Bergan et al., 2015) indicate that the lipolytic actions of GH can

312 be modulated in a physiological manner by nutritional state. This work is consistent with

313 findings in the liver of mice where nutritional state has been shown to modulate (reduced by high

314 fat diet) the lipolytic effects of GH (Yang et al., 2013).

315 INS and IGF-1 underlie the nutritional regulation of GH-stimulated lipolysis. This contention

316 is supported by several observations. First, both INS and IGF-1 are closely regulated by

317 nutritional state: plasma levels of INS and IGF-1 peak postprandially but are diminished during

318 fasting (Caruso and Sheridan, 2011; Norbeck et al., 2007; Shimizu et al., 2009; Stone, 2003).

319 Second, this work indicated that cells pretreated with serum from fasted animals (when levels of

320 INS and IGF-1 are reduced) resulted in enhanced HSL expression compared to cells treated with

321 serum from fed animals (when levels of INS and IGF-1 are elevated). Third, INS and IGF-1 had

322 no effect on GH-stimulated expression of HSL mRNAs in cells from fed animals, whereas INS

323 and IGF-1 blocked GH-stimulated expression of HSL mRNAs in cells from fasted animals. It

324 should be noted that the nature of serum is undefined and it may be that factors in addition to GH

325 or IGF-1 contribute to the observed effects. Regardless, these findings are consistent with the 
anabolic actions of INS and IGF-1 (Caruso and Sheridan, 2011) as well as with the specific anti-

327 lipolytic actions of INS in mammals. For example, INS inhibits activation of HSL in fish

328 (Sheridan, 1994) and attenuated fasting-stimulated lipolysis in mammals to control levels

329 (Schneider et al., 2011).

330 Nutritional state dictates to which signaling pathways GHR link. Under fed conditions,

331 GH activates JAK2, STAT5, Akt, and ERK. Evidence for this comes from the current

332 observation that GH stimulated increased abundance of phospho-JAK2, STAT5, Akt, and

333 ERK1/2 when cells were pretreated with serum from fed fish despite the nutritional environment

334 from which the cells came. These pathways have been linked to GH-stimulated growth

335 promotion previously (Reindl et al., 2011). By contrast, under fasting conditions, GH links to

336 ERK and PKC. This is evident from our current observations that when cells were pretreated

337 with serum collected from fasted fish, despite the nutritional environment from which they came

338 (fed or fasted), GH increased the abundance of phospho-PKC; this did not occur in cells

339 pretreated with serum from fed fish. These results are consistent with our previous observations

340 that nutrition influences the activation of signaling pathways (Bergan et al., 2012) as well as on

341 signal pathways known to link to GHR and to pathways know to activate HSL in fish and

342 mammals (Bergan et al., 2013, 2015; González-Yanes and Sánchez-Margalet, 2006; Gorin et al., 343 1990).

344 INS and IGF-1 alter the activation of GH-stimulated pathways to reflect a fed-like state. This 345 conclusion is supported by the observation that INS and/or IGF-1 pretreatment augmented GH346 stimulated increases in phospho-JAK2 and STAT5 in both cell types (fed and fasted) — pathways 347 associated with the fed state and known to mediate growth promotion (Reindl et al., 2011;

348 Walock et al., 2011). Moreover, GH-stimulated phosphorylation of PKC (which has been shown 
349 to link to lipolysis in fish and mammals, cf. Bergan et al., 2013; Gorin et al., 1990) was abolished 350 when cells were pretreated with INS and/or IGF.

351 The mechanisms by which INS and IGF-1 alter pathway linkages to modulate the actions 352 of GH are not fully known. INS and IGF-1 signaling involves numerous, interacting pathways 353 (Caruso and Sheridan, 2011), some of which are in common with pathways that influence growth 354 in fish as well as in mammals, such as JAK/STAT, ERK, and Akt/PI3K (Martinez et al., 2013; 355 Reindl et al., 2011). Our current findings suggest that when GH is present with INS and/or IGF-1 356 (which occurs during periods of feeding) intracellular signaling becomes aligned with growth357 promoting processes. This is supported by the observation in mammals that IGF-1R was required 358 for GH to activate STAT5 in osteoblasts - an action that was mediated by inhibition of protein 359 tyrosine phosphatase 1B (PTP1B)(which degrade JAK/STAT)(Gan et al., 2013). Concomitantly, 360 INS activates pathways that prevent GHR linkage to pathways that activate lipolysis. For 361 example, INS inhibits catecholamine-stimulated lipolysis in mammals by blocking signal 362 transduction from adrenergic receptors through PKC $\beta I$ (Nakamura, 2007). Additionally, insulin 363 can work through PI3K/Akt to degrade cAMP and therefore block activation of PKA, which 364 phosphorylates HSL and results in its activation (González-Yanes and Sánchez-Margalet, 2006). 365 In the absence of INS (as during periods of fasting), cAMP is not degraded, PKC $\beta$ I signaling is 366 not inhibited, and GH-signaling shifts away from JAK/STAT- and Akt/PI3K-stimulated growth

367 (Reindl et al., 2011) to PKC- activated lipolysis. Moreover, in the absence of IGF-1 (also as 368 during periods of fasting), the inhibition of PTP1B is lifted, resulting in the degradation of 369 JAK/STAT and contributing further to the shift away from GH-stimulated growth to GH370 stimulated lipolysis. 
In summary, the current findings provide novel insight into the molecular basis of the multi-

372 functionality of GH and help resolve its disparate anabolic (growth promoting) and catabolic

373 (lipolytic) actions. Figure 5 illustrates the pathways involved with the activation of lipolysis and

374 the influence of insulin and IGF-1 on these pathways. During periods of feeding, the anabolic,

375 growth-promoting actions During periods of feeding, the anabolic, growth-promoting actions of

376 GH results from GHRs linking to JAK/STAT and Akt/PI3K — linkages that are enabled by the

377 presence of INS and IGF-1. During periods of fasting, the absence of INS and IGF-1

378 "reprograms" cells such that GHR linkages to JAK/STAT and Akt/PI3K are disabled and linkage

379 of GHR to PKC is enabled and the activation of HSL and lipolysis ensues. Such metabolic

380 switching is adaptive because it provides a means of promoting growth when nutrients are

381 available and inhibiting growth when nutrients are not available while concomitantly mobilizing

382 the stored energy reserves necessary for sustaining maintenance metabolism. It also helps

383 explain the apparent enigma of growth cessation in the face of sustained (or elevated) plasma

384 levels of GH during periods of fasting (cf. Norbeck et al., 2007).

\section{Acknowledgements}

387 We would like to thank Chad Walock, Dillon Marquart, Lindsey Norbeck, Andrea

388 Hanson, Lincoln Martin, Elizabeth Ellens, and Nicholas Galt for their assistance. We also thank

389 Prof. Akiyoshi Takahashi and Dr. Shinsuke Moriyama for generously providing salmonid GH.

390 This work was supported by National Science Foundation grant IOS 0920116 to M.A. Sheridan;

391 H.E. Bergan-Roller was supported by a ND EPSCoR fellowship funded by NSF (EPS0814442). 


\section{References}

394 Albalat, A., Gomez-Requeni, P., Rojas, P., Medale, F., Kaushik, Vianen, G.J., Van den Thillart,

Caruso, M.A., Sheridan, M.A., 2011. New insights into the signaling system and function of

Butler, A.A., Roith, D.L., 2001. Control of Growth by the Somatropic Axis: Growth Hormone

Birzniece, V., Sata, A. and Ho, K.K., 2009. Growth hormone receptor modulators. Rev. Endocr. Metab. Disord. 10, 145-156. insulin in fish. Gen. Comp. Endocrinol. 173, 227-247. and the Insulin-Like Growth Factors Have Related and Independent Roles. Annu. Rev. Physiol. 63, 141-164.

Carrel, A.L., Allen, D.B., 2000. Effects of growth hormone on adipose tissue. J. Pediatr. Endocrinol. Metab. 13, 1003-1009. 
Biophys. Res. Commun. 324, 1218-1222.

417 Duan, C., Xu, Q., 2005. Roles of insulin-like growth factor (IGF) binding proteins in regulating IGF actions. Gen. Comp. Endocrinol. 142, 44-52.

419 Galt, N.J., Froehlich, J.M., Meyer, B.M., Barrows, F.T., Biga, P.R., 2014. High-fat diet reduces local myostatin-1 paralog expression and alters skeletal muscle lipid content in rainbow trout, Oncorhynchus mykiss. Fish Physiol. Biochem. 40(3), 875-886.

Gan, Y., Zhang, Y., Buckels, A., Paterson, A.J., Jiang, J., Clemens, T.L., Zhang, Z-Y., Du, K., Chang, Y., Frank, S. J., 2013. IGF-1R modulation of acute GH-induced STAT5 signaling: roles of protein tyrosine phosphotase activity. Mol. Endocrinol. 27, 1969-1979.

González-Yanes, C., Sánchez-Margalet, V., 2006. Signalling mechanisms regulating lipolysis.

\section{7}

Cell. Signal. 18, 401-408.

Gorin, E., Tai, L., Honeyman, T.W., Goodman, H.M., 1990. Evidence for a role of protein kinase $\mathrm{C}$ in the stimulation of lipolysis by growth hormone and isoproterenol. Endocrinol. 126, 2973-2982.

Harmon, J.S., Sheridan, M.A., 1992. Effects of nutritional state, insulin, and glucagon on lipid mobilization in rainbow trout, Oncorhynchus mykiss. Gen. Comp. Endocrinol. 87, 214-221.

Kirchner, S., Panserat, S., Lim, P.L., Kaushik, S., Ferraris, R.P., 2008. The role of hepatic, renal and intestinal gluconeogenic enzymes in glucose homeostasis of juvenile rainbow trout. J. Comp. Physiol. B. 178, 429-438.

Kittilson, J.D., Reindl, K.M., Sheridan, M.A., 2011. Rainbow trout (Oncorhynchus mykiss) possess two hormone-sensitive lipase-encoding mRNAs that are differentially expressed and independently regulated by nutritional state. Comp. Biochem. Physiol. A 158, 52-60. 
Lafontan, M., Langin, D., 2009. Lipolysis and lipid mobilization in human adipose tissue. Prog. Lipid. Res. 48, 275-297.

Martinez, C.S., Piazza, V. G., Ratner, L.D., Matos, M.N., González, L., Rulli, S.B., Sotelo, A.I., 2013. Growth hormone STAT5-mediated signaling and its modulation in mice liver during the growth period. Growth Horm. IGF Res. 23(1-2), 19-28.

Mommsen, T.P., Moon, T.W., Walsh, P.J., 1994. Hepatocytes: isolation, maintenance, and utilization. In: Hochachka, P.W., Mommsen, T.P. (Eds.), Biochemistry and Molecular Biology of Fish. Elsevier, New York, pp. 355-373.

Mommsen, T.P., Plisetsakya, E.M., 1991. Insulin in fishes and agnathans- history, structure, and metabolic regulation. Rev. Aquat. Sci. 4, 225-259.

Nakamura, J., 2007. Protein kinase C-dependent antilipolysis by insulin in rat adipocytes. Biochim. Biophys. Acta. 1771, 1195-1201.

Norbeck, L.A., Kittilson, J.D., Sheridan, M.A., 2007. Resolving the growth-promoting and metabolic effects of growth hormone: differential regulation of GH-IGF-I system components. Gen. Comp. Endocrinol. 151, 332-341.

O’Connor, P.K., Reich, B., Sheridan, M.A., 1993. Growth hormone stimulates hepatic lipid mobilization in rainbow trout, Oncorhynchus mykiss. J. Comp. Physiol. B 163, 427-431.

Pierce, A.L., Shimizu, M., Beckman, B.R., Baker, D.M., Dickhoff, W.W., 2005. Time course of the GH/IGF axis response to fasting and increased ration in chinook salmon (Oncorhynchus tshawytscha). Gen. Comp. Endocrinol. 140, 192-202.

Reinecke, M., Björnsson, B.T., Dickhoff, W.W., McCormick, S. D., Navarro, I., Power, D. M., \& Gutiérrez, J., 2005. Growth hormone and insulin-like growth factors in fish: Where we are and where to go. Gen. Comp. Endocrinol. 142, 20-24. 
462

463

464

465

466

467

468

469

470

471

472

473

474

475

476

477

478

479

480

481

482

483

484

Reindl, K.M., Kittilson, J.D., Bergan, H.E., Sheridan, M.A. 2011. Growth hormone-stimulated insulin-like growth factor-1 expression in rainbow trout (Oncorhynchus mykiss) hepatocytes is mediated by ERK, PI3K-AKT, and JAK-STAT. Am. J. Physiol. 301, R236-R243.

Richelsen, B., 1997. Action of growth hormone in adipose tissue. Horm. Res. 48: 105-110.

Salgin, B., Marcovecchio, M.L., Hill, N., Dunger, D.B., Frystyk, J., 2012. The effect of prolonged fasting on levels of growth hormone-binding protein and free growth hormone. Growth Horm. IGF Res. 22, 76-81.

Schneider, A., Pfeifer, L.F.M., da Silva Neto, J.W., Hax, L.T., Antunes, M.M., Del Pino, F.A.B., Paludo, G.R., Corrêa, M.N., 2011. Effect of exogenous insulin and fasting on growth hormone receptor and IGF-I expression in the pre-ovulatory follicle of ewes. Animal 5, $1420-1425$.

Sheridan, M.A., 1994. Regulation of lipid metabolism in poikilothermic vertebrates. Comp. Physiol. Biochem. B 107, 495-508.

Sheridan, M.A., Mommsen, T.P., 1991. Effects of nutritional state on in vivo lipid and carbohydrate metabolism of coho salmon, Oncorhynchus kisutch. Gen. Comp. Endocrinol. 81, 473-483.

Shimizu, M., Cooper, K.A., Dickhoff, W.W., Beckman, B.R., 2009. Postprandial changes in plasma growth hormone, insulin, insulin-like growth factor (IGF)-I, and IGF-binding proteins in coho salmon fasted for varying periods. Am. J. Physiol. Regul. Integr. Comp. Physiol. 297, R352-R361.

Sos, B.C., Harris, C., Nordstrom, S.M., Tran, J.L., Balázs, M., Caplazi, P., Weiss, E.J., 2011. Abrogation of growth hormone secretion rescues fatty liver in mice with hepatocyte- 
specific deletion of JAK2. J. Clin. Invest. 121, 1412-1423.

486 Stone, D. A.J., 2003. Dietary carbohydrate utilization by fish. Rev. Fish. Sci. 11, 337-369.

487 Taniguchi, C.M., Emanuelli, B., Kahn, C.R., 2006. Critical nodes in signalling pathways:

488 insights into insulin action. Nat. Rev. Mol. Cell. Biol. 7, 85-96.

489 Walock, C.N., Martin, L., Kittilson, J.D., Sheridan, M.A., 2011. Differential effects of growth

490 hormone family peptides on the expression of insulin-like growth factor 1 and 1 mRNAs.

$491 \quad$ Front. Endocrinol. doi: 10.3389/conf.fendo.2011.04.00059

492 Watt, M.J., Spriet, L.L., 2010. Triacylglycerol lipase and metabolic control: implication for

493 health and disease. Am. J. Physiol. Endocrinol. Metab. 299, E162-E168.

494 White, M.F., 2003. Insulin signaling in health and disease. Science 302, 1710-1711.

495 Yang, H.L., Feng, M., Tan, X., Yan, G.Y., Sun, C., 2013. The role of SOCS2 in recombinant

496 human growth hormone (rhGH) regulating lipid metabolism in high-fat-diet-induced

497 obesity mice. Mol. Biol. Rep. 40, 2319-2326.

498 


\section{Legends to Figures}

500 Figure 1. Effects of serum and growth hormone $(\mathrm{GH})$ treatment on expression of hormone

Figure 2. Effects of serum and growth hormone $(\mathrm{GH})$ on the abundance of phosphorylated Janus kinase 2 (JAK2), signal transducer and activator of transcription 5 (STAT5), protein kinase B (Akt), extracellular signal-regulated kinase (ERK), and protein kinase C (PKC) in isolated hepatocytes of rainbow trout fed continuously (A, C, E, G, I) or fasted for 4 weeks (B, D, F, H, J). Cells were incubated for 24 hours with $10 \%$ serum harvested from the blood plasma of fed or fasted fish and with or without $100 \mathrm{ng} / \mathrm{ml}$ of $\mathrm{GH}$ for an additional 30 minutes. Cell lysates were separated by SDS-PAGE followed by Western immunoblotting, and the blots were quantified with a FluorChem imager. The abundance of phosphorylated JAK2, STAT5, Akt, ERK1/2, and PKC $\alpha / \beta$ II was normalized to total JAK2, STAT5, Akt, ERK1/2, and $\beta$-actin respectively. Data are presented as \% control from fed cells-fed serum control and expressed as mean + SEM $(n=6)$. Groups with different letters are significantly $(\mathrm{p}<0.05)$ different.

Figure 3. Effects of insulin (INS), insulin-like growth factor (IGF-1), and growth hormone (GH) 
treatment on expression of hormone sensitive lipase (HSL) 1- and HSL2-encoding mRNAs from isolated hepatocytes of rainbow trout (A) fed continuously or (B) fasted for 4 weeks. Cells were pretreated for 24 hours with or without $100 \mathrm{ng} / \mathrm{ml} \mathrm{INS} \mathrm{and/or} 200$ $\mathrm{ng} / \mathrm{ml} \mathrm{IGF-1} \mathrm{then} \mathrm{treated} \mathrm{with} \mathrm{or} \mathrm{without} 100 \mathrm{ng} / \mathrm{ml}$ of $\mathrm{GH}$ for an additional 6 hours. Steady-state levels of mRNA were determined by quantitative real-time RT-PCR as described in the materials and methods section. Data are presented as \% control from fed cell control and expressed as mean $\underline{+} \operatorname{SEM}(n=6)$. Groups with different letters are significantly $(\mathrm{p}<0.05)$ different.

Figure 4. Effects of insulin (INS), insulin-like growth factor (IGF-1), and growth hormone (GH) on the abundance of phosphorylated Janus kinase 2 (JAK2), signal transducer and activator of transcription 5 (STAT5), extracellular signal-regulated kinase (ERK), and protein kinase $\mathrm{C}(\mathrm{PKC})$ in isolated hepatocytes of rainbow trout $(\mathrm{A}, \mathrm{C}, \mathrm{E}, \mathrm{G})$ fed continuously or (B, D, F, H) fasted for 4 weeks. Cells were pretreated for 24 hours with or without $100 \mathrm{ng} / \mathrm{ml} \mathrm{INS} \mathrm{and/or} 200 \mathrm{ng} / \mathrm{ml} \mathrm{IGF-1} \mathrm{then} \mathrm{treated} \mathrm{with} \mathrm{or} \mathrm{without} 100 \mathrm{ng} / \mathrm{ml}$ of GH for an additional 30 minutes. Cell lysates were separated by SDS-PAGE followed by Western immunoblotting, and the blots were quantified with a FluorChem imager. The abundance of phosphorylated JAK2, STAT5, ERK1/2, and PKC $\alpha / \beta$ II was normalized to total JAK2, STAT5, ERK1/2, and $\beta$-actin respectively. Data are presented as $\%$ control from fed cell control and expressed as mean \pm SEM $(n=6)$. Groups with different letters are significantly $(\mathrm{p}<0.05)$ different.

Figure 5. Model of differential growth hormone (GH)-signal pathway linkages and the activation of growth-promoting or lipid mobilizing (lipolysis) responses. Nutritional state (anabolic or catabolic), insulin (INS), and insulin-like growth factor (IGF)-1 modulate pathway 
linkages. GH-stimulated lipolysis (as reflected by hormone-sensitive lipase, HSL, activation/expression) prevails with activation of PLC/PKC/ERK pathways under catabolic (e.g., fasting, absence of INS and/or IGF-1) conditions. Lipolysis is deactivated under anabolic (e.g., feeding, presence of INS and/or IGF-1) conditions as signal linkages switch away from the PLC/PKC/ERK pathways to the JAK-STAT and PI3K-Akt pathways. In addition, crosstalk via Akt activation of phosphodiesterase, PDE, further suppresses lipolysis by degrading cAMP during anabolic conditions 


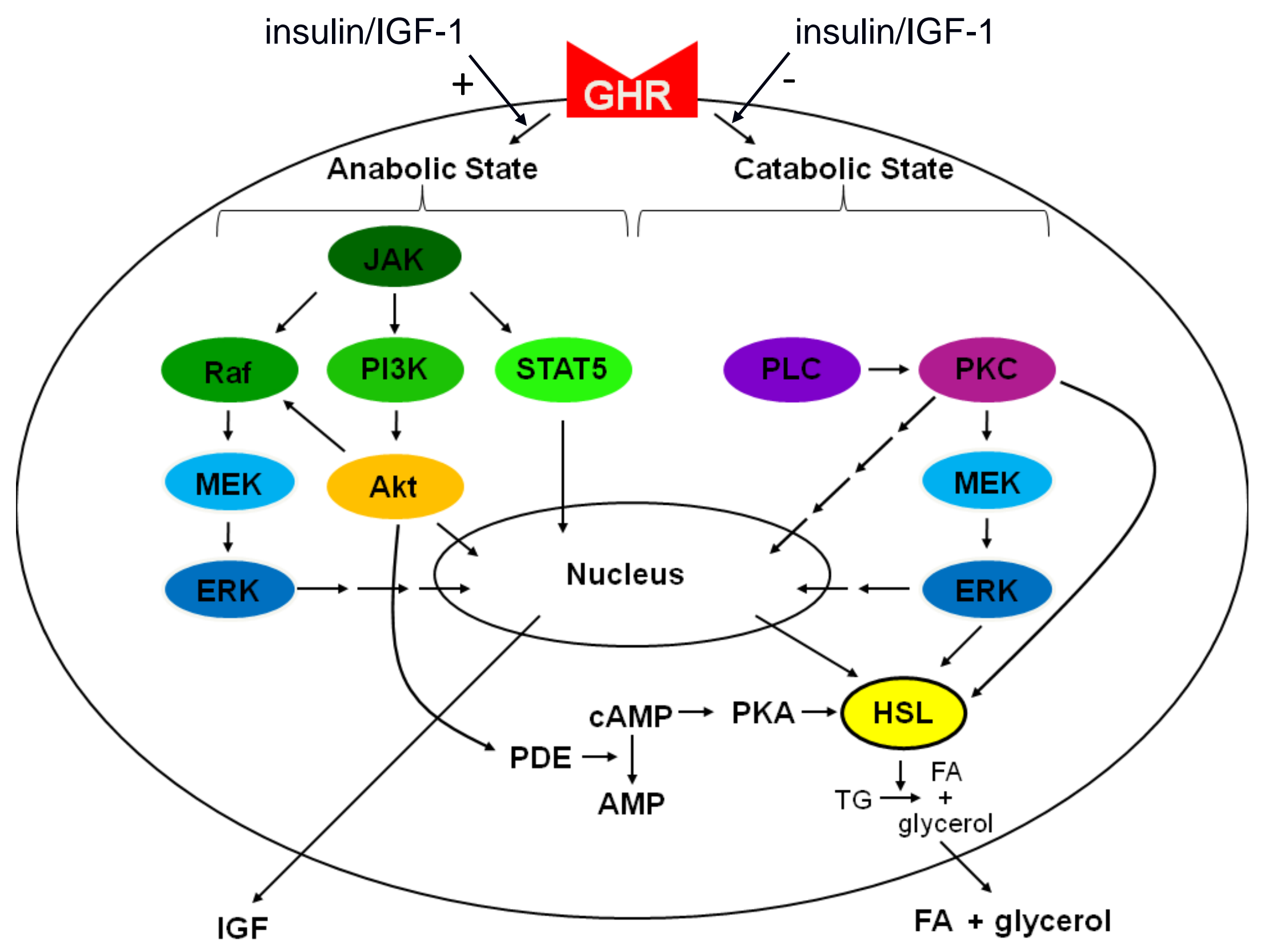


Figure 1

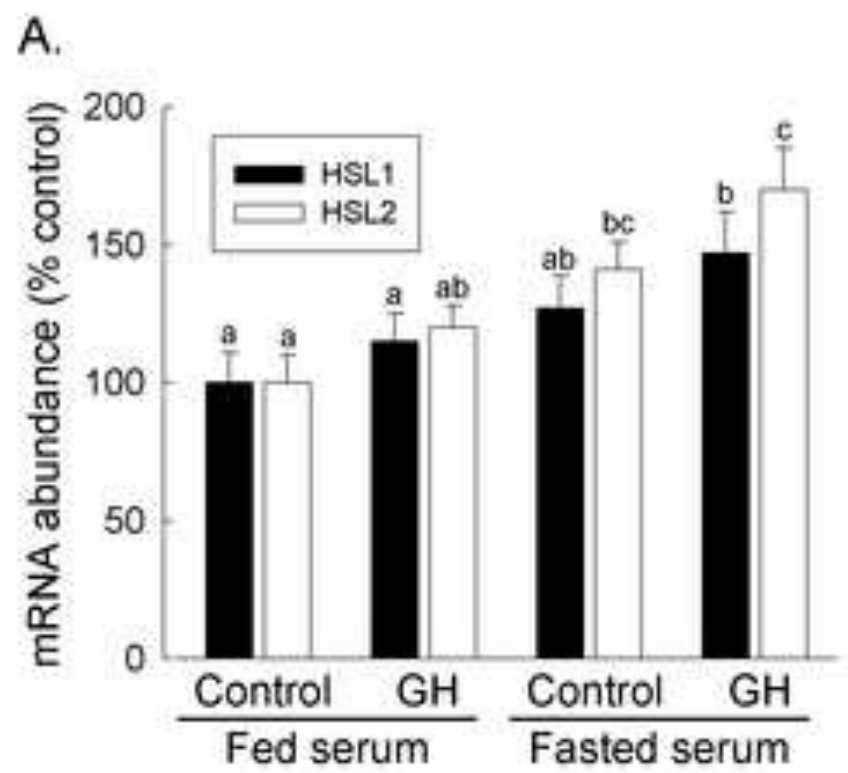

B.

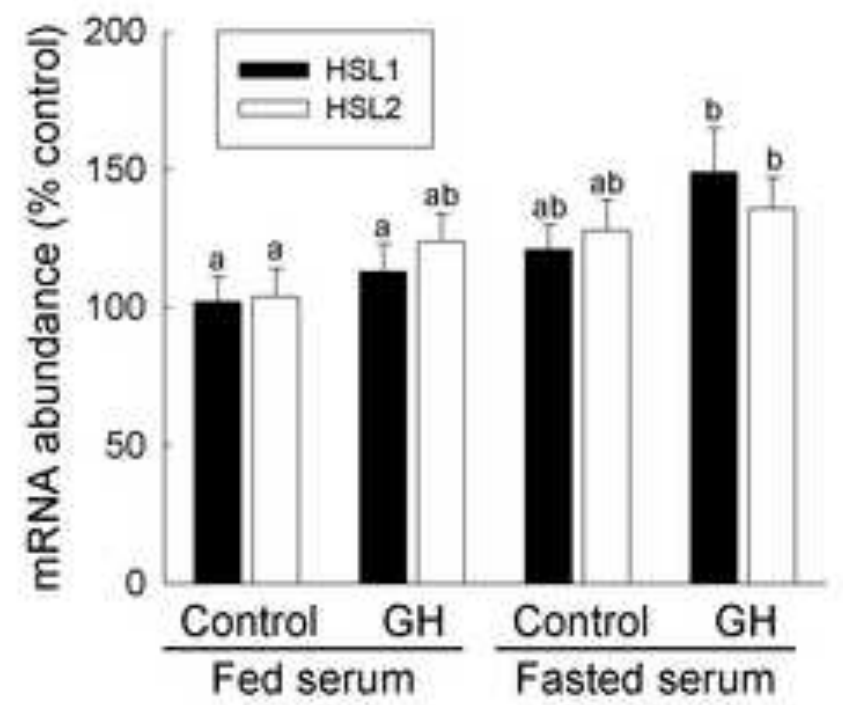


Figure 2

A.

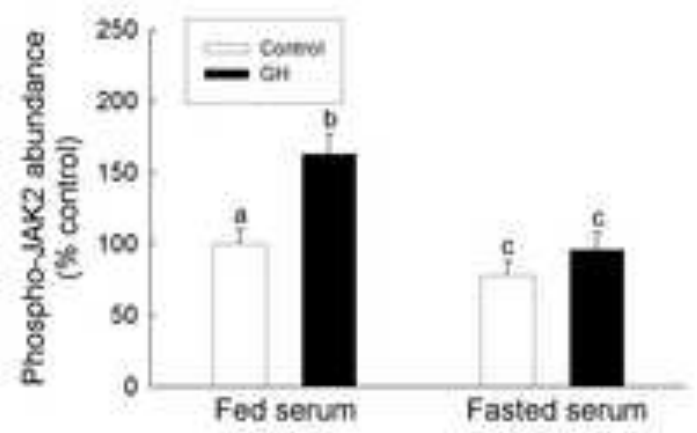

c.

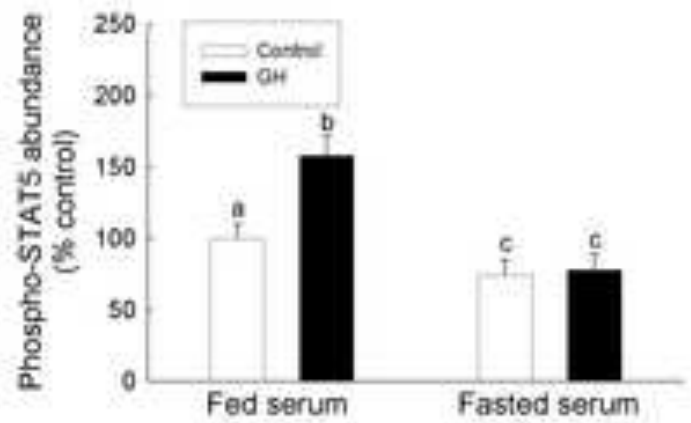

E.

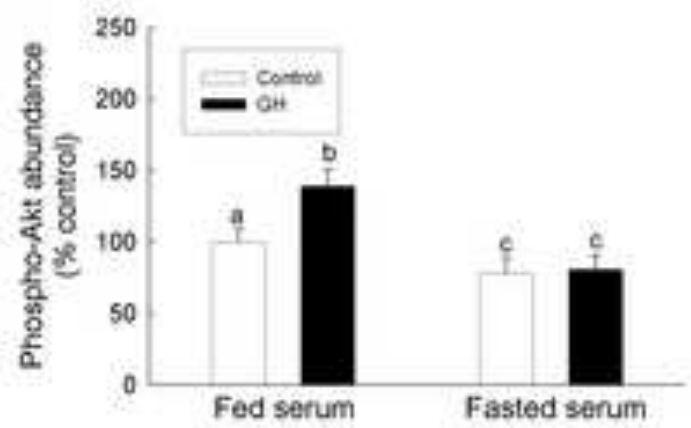

G.

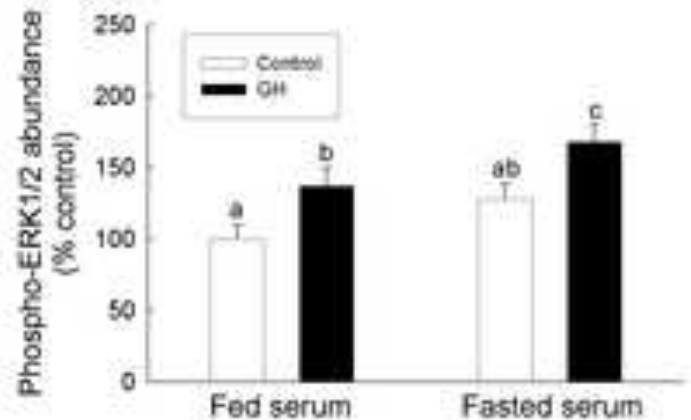

1.

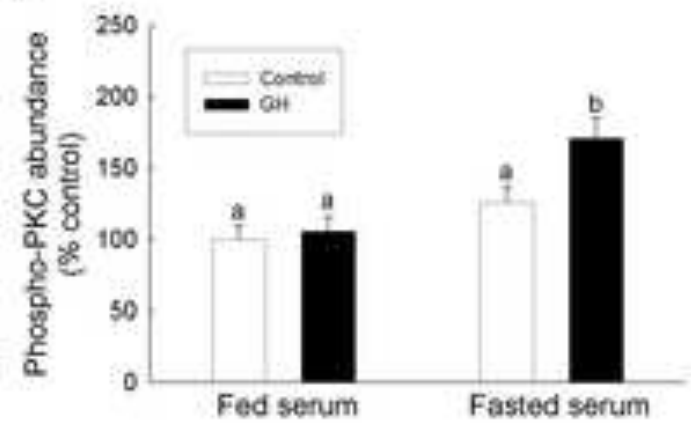

B.

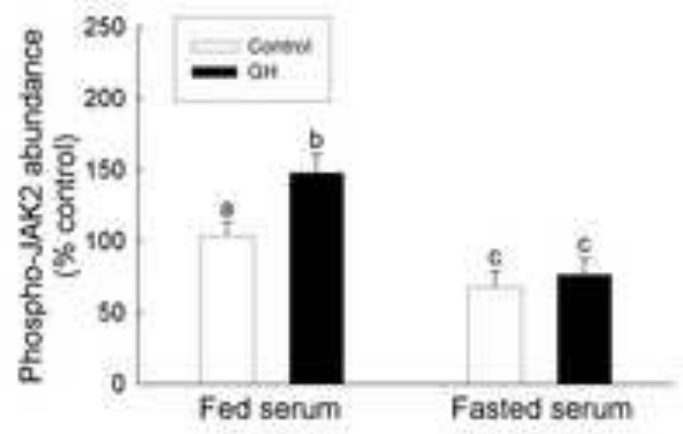

D.

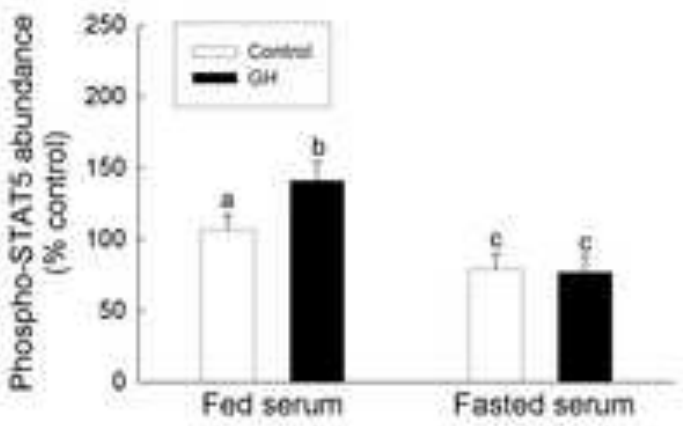

F.

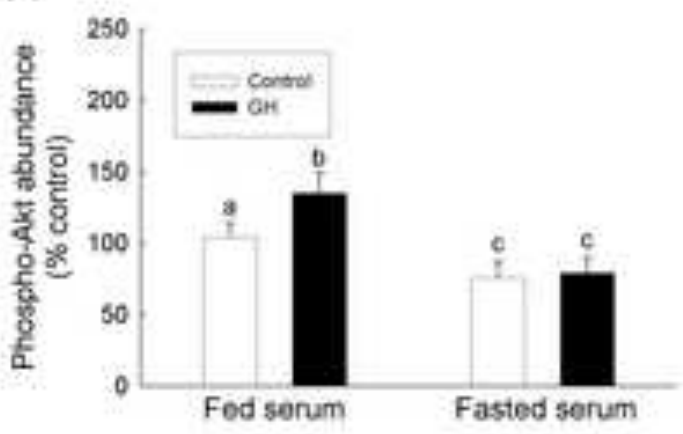

H.

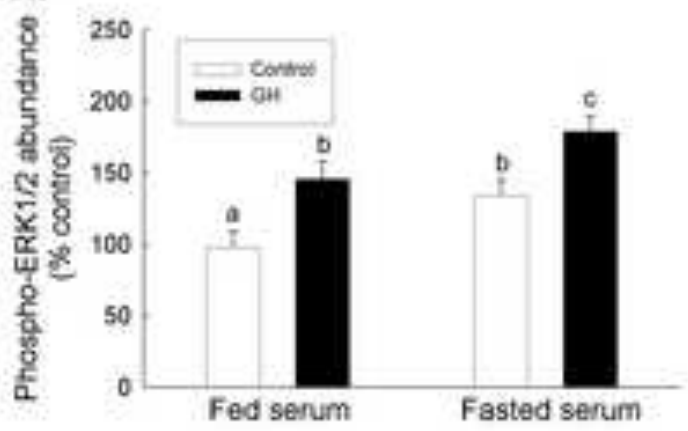

J.

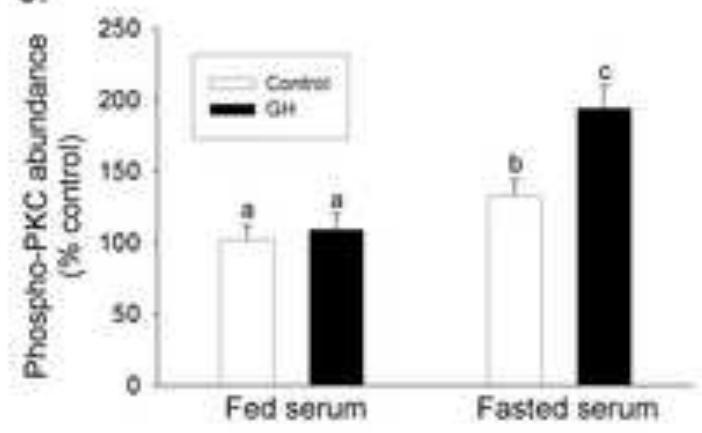


A.

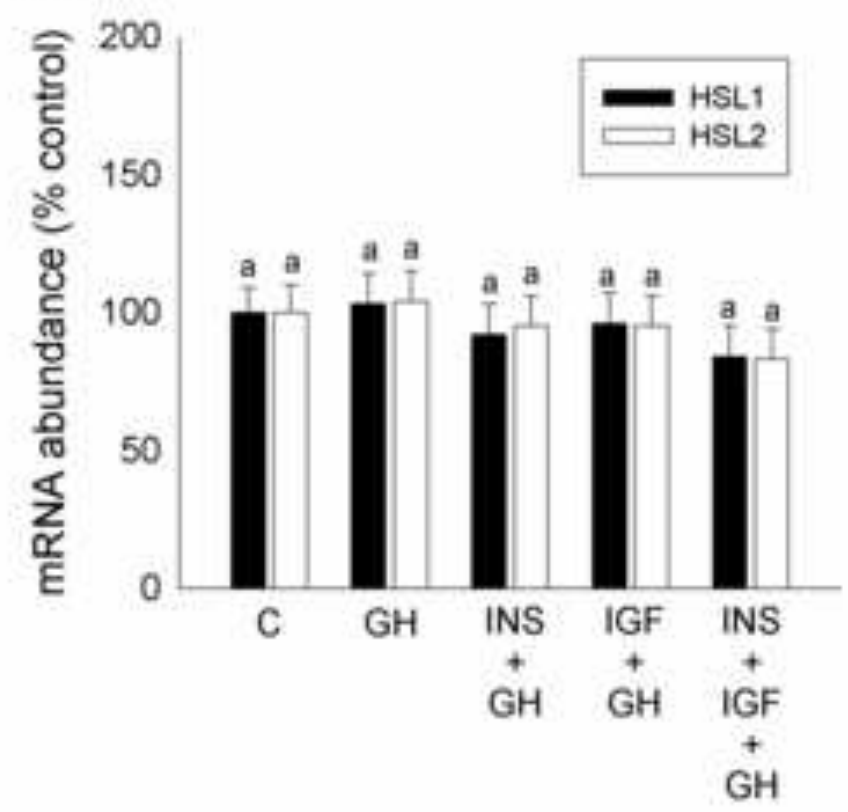

B.

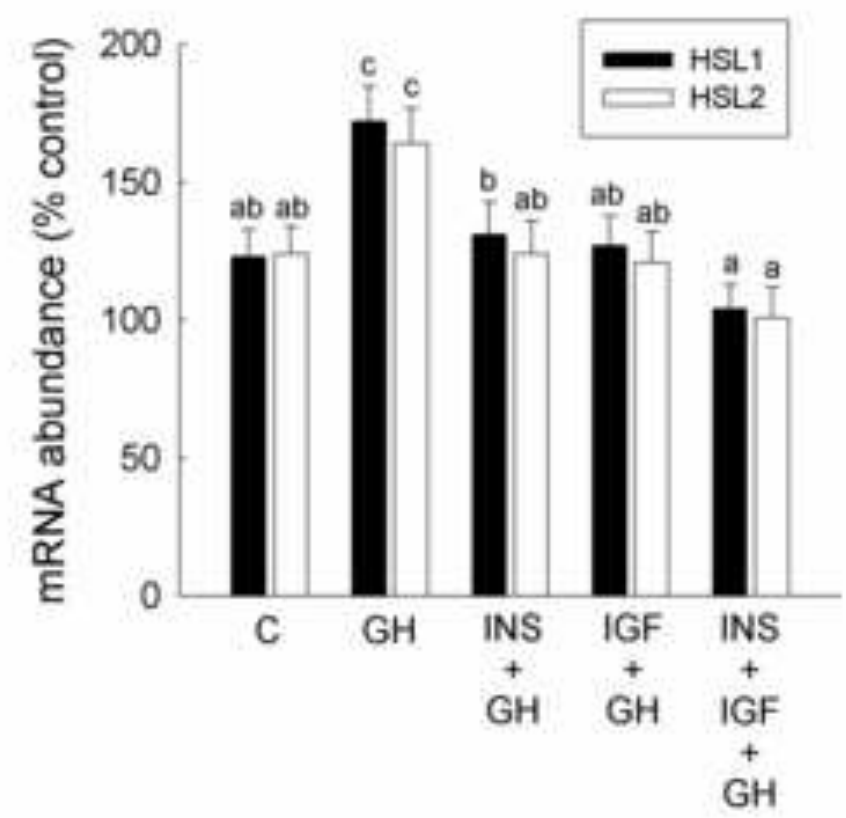

A.

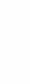

B.

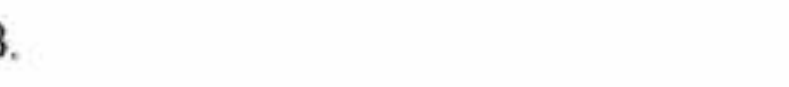

GH 
Figure 4

A.

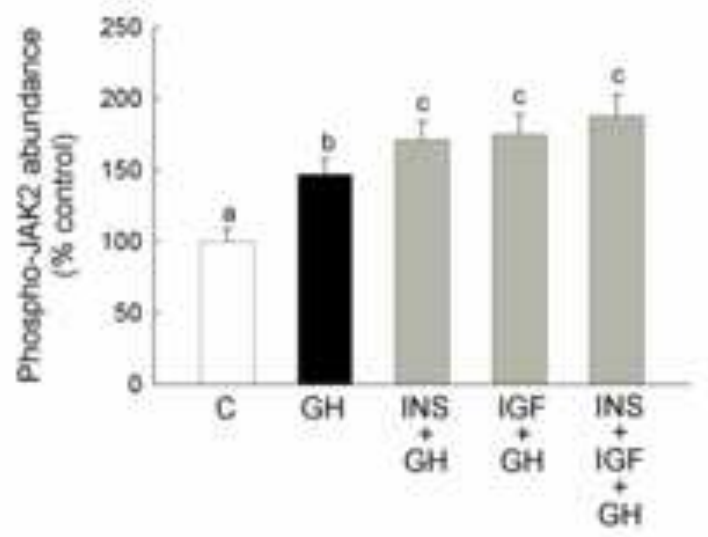

c.

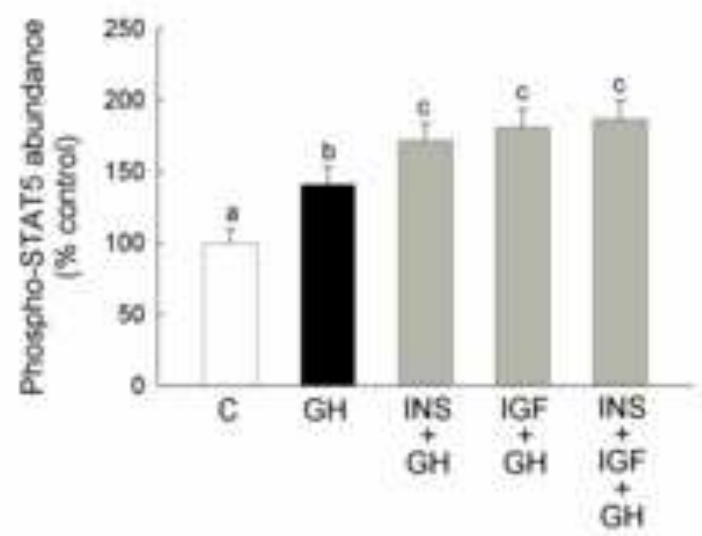

E.

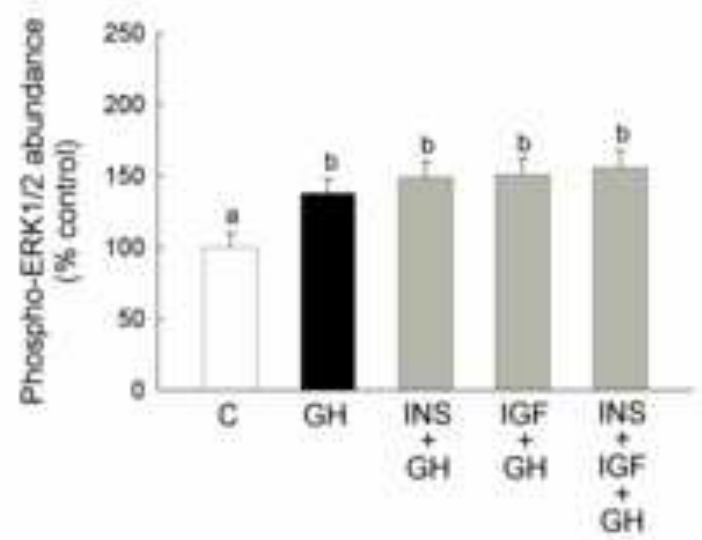

G.

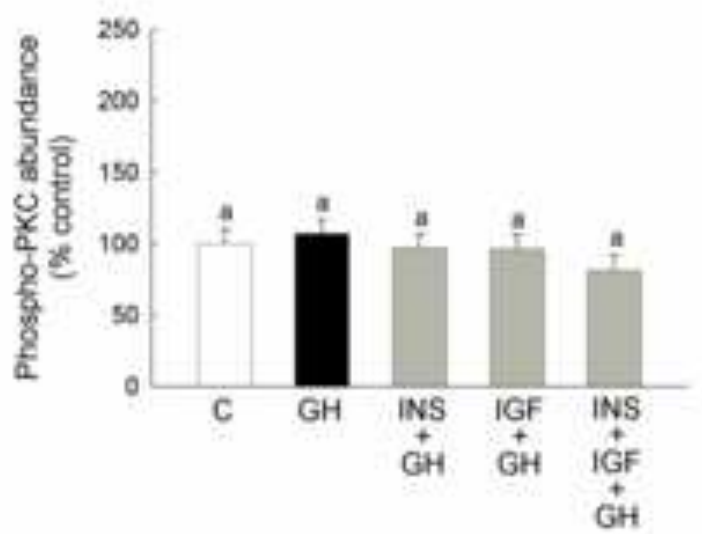

B.

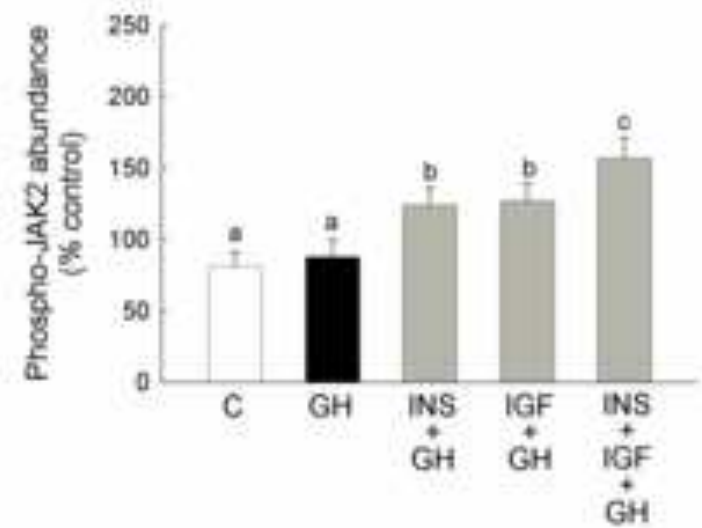

D.

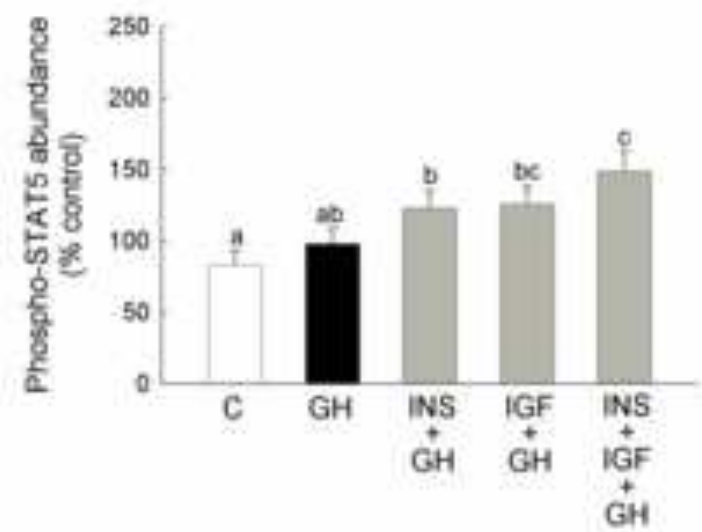

F.

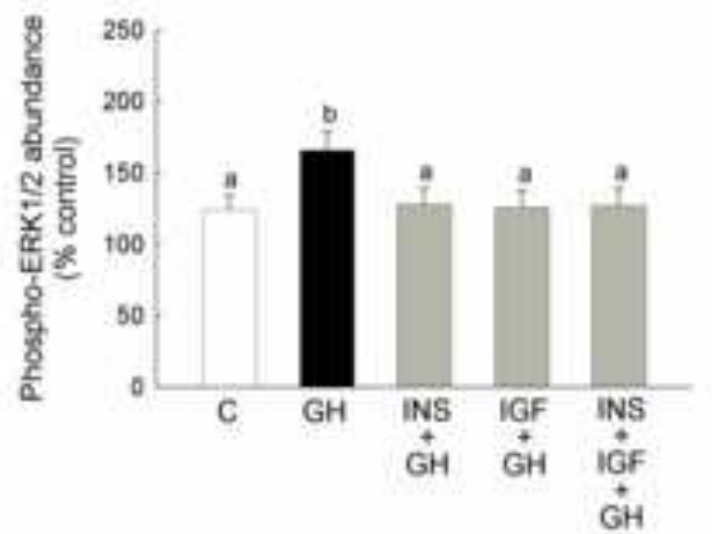

H.

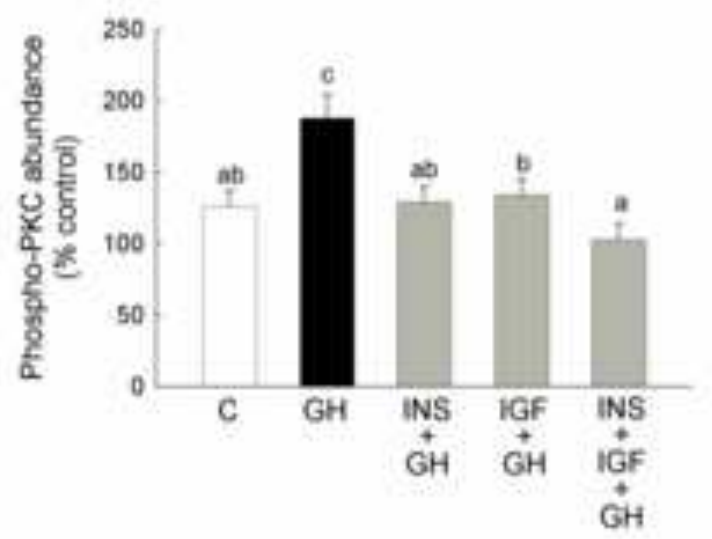




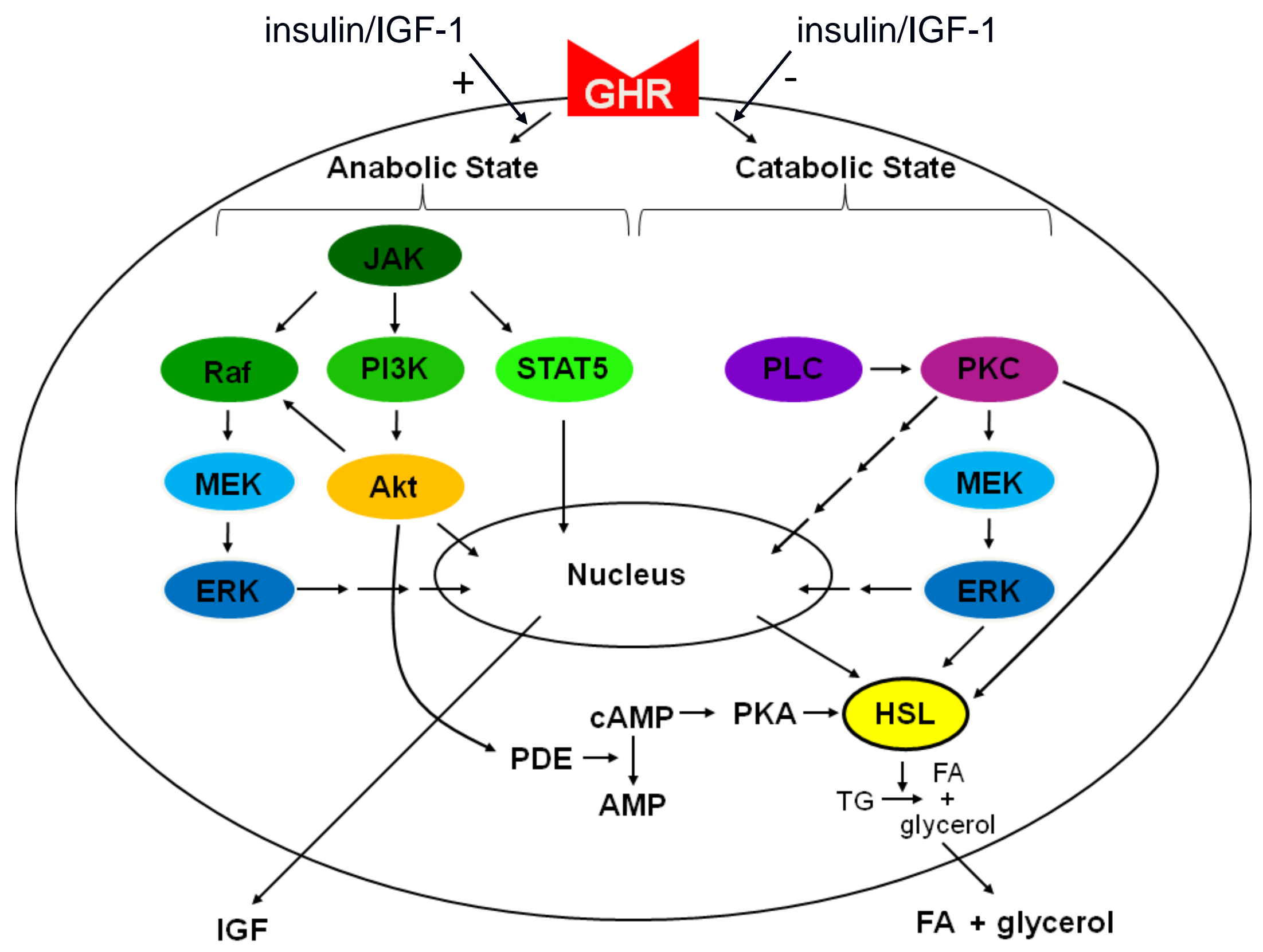

